\title{
A Neo-Gramscian Approach to Corporate Political Strategy: Conflict and Accommodation in the Climate Change Negotiations*
}

\section{David L. Levy and Daniel Egan}

\author{
University of Massachusetts, Boston; University of Massachusetts, Lowell
}

ABstract A neo-Gramscian theoretical framework for corporate political strategy is developed drawing from Gramsci's analysis of the relations among capital, social forces, and the state, and from more contemporary theories. Gramsci's political theory recognizes the centrality of organizations and strategy, directs attention to the organizational, economic, and ideological pillars of power, while illuminating the processes of coalition building, conflict, and accommodation that drive social change. This approach addresses the structure-agency relationship and endogenous dynamics in a way that could enrich institutional theory. The framework suggests a strategic concept of power, which provides space for contestation by subordinate groups in complex dynamic social systems. We apply the framework to analyse the international negotiations to control emissions of greenhouse gases, focusing on the responses of firms in the US and European oil and automobile industries. The neoGramscian framework explains some specific features of corporate responses to challenges to their hegemonic position and points to the importance of political struggles within civil society. The analysis suggests that the conventional demarcation between market and non-market strategies is untenable, given the embeddedness of markets in contested social and political structures and the political character of strategies directed toward defending and enhancing markets, technologies, corporate autonomy and legitimacy.

\section{INTRODUGTION}

Despite the resurgence of concerns about the dominance of corporate influence and the triumph of neoliberalism (Korten, 1995; Robinson, 1996), a number of important developments contradict the image of corporations as all-powerful juggernauts: efforts to create a Multilateral Agreement on Investment have stalled Massachusetts, Boston, Boston, Massachusetts 02125, USA (David.Levy@umb.edu). 
(Smythe, 2000), and Monsanto's efforts to commercialize genetically modified food and seeds have faltered (Eichenwald et al., 200l). More broadly, the wave of environmental activism in the USA and Europe that began in 1960s and 1970s has forced companies to develop techniques of environmental management that ameliorate the more egregious environmental impacts of their business operations, and to reconstruct themselves as responsible stewards of the environment (Buttel, 1998; Levy, 1997). These cases suggest that corporate power is constrained and contested by environmental, labour, and other social forces.

The prospect of mandatory curbs on production and use of fossil fuels to reduce the impact of greenhouse gases (GHG) on the Earth's climate system poses a serious economic threat to corporate actors across a wide range of industries. Newell and Paterson (1998, p. 682) conclude that 'when the centrality of fossil fuels in producing global warming is combined with the centrality of fossil energy in industrial economies, it becomes clear that the fundamental interests of major sectors of those economies are threatened by proposals to limit greenhouse gas emissions.' The fossil fuel industry's initial response to this threat was aggressive and unsurprising. US-based companies in the coal, oil, automobile, utility, and chemicals industries formed industry associations, lobbied politicians, challenged the science of climate change, and pointed to the high costs of reducing emissions. Despite the apparent success of these efforts in influencing US policy, by 1998 industry appeared to be changing its stance toward a more accommodative position and companies were beginning to invest substantial amounts in low-emission technologies. No obvious dramatic scientific, technological, or regulatory developments can account for these changes; the prospects for ratification in the US Senate of the 1997 Kyoto Protocol, which would commit the USA to a 7 per cent reduction in greenhouse gas emissions from 1990 levels, were slim even before the ascendancy of the Bush administration in November 2000.

The existing literature on corporate political strategy (CPS) does not account well for the multiple forms of industry responses to social pressures nor for the dynamics of conflict and accommodation by which contentious issues evolve. Managerialist discussions of CPS have been relatively atheoretical, providing a more empirical and descriptive framework somewhat disengaged from broader streams of social theory. Early writing in the field stressed the importance of developing a proactive political strategy (Mahon, 1983; Weidenbaum, 1981; Yoffie and Bergenstein, 1985), while more recent contributions have examined firm-level and institutional variables that affect the political strategy formulation process (Boddewyn, 1988; Hillman and Keim, 1995; Steger, 1993). Only recently has this literature turned its attention to the choice of specific strategies and channels of influence (Shaffer, 1995). Hillman and Hitt (1999), for example, offer three generic strategies - providing information, financial incentives, and constituency building - but in doing so reinforce the distinction between CPS and market-oriented strategies. Companies are generally portrayed as responding to external public and 
regulatory pressures in pluralist competition with other social actors (Mitnick, 1993; Vogel, 1996), while the CPS literature neglects broader political and economic structures within which these contests are embedded.

Power structure and élite theories provide more theoretically grounded accounts of business-society relations, emphasizing the institutional mechanisms by which a relatively cohesive élite dominates politics (Domhoff, 1990; Mills, 1967; Mizruchi, 1992; Useem, 1984). In Domhoff's formulation, the power élite has three allied components: an upper class defined by a network of institutions and the concentrated ownership of wealth; a corporate community of directors, managers, and business - professionals with its own set of institutional networks; and a policy formation network of nonprofit organizations such as foundations and think tanks that develop and disseminate political strategies and policies. While some writers in this tradition have examined the contingency of business cohesion (Akard, 1992; Ferguson, 1995), this perspective does not pay sufficient attention to rivalry among factions of the dominant class, the dynamics of contestation and accommodation with other social groups, or ideological dimensions of power.

To explain the dynamics of CPS in response to the climate change issue, we turn to the work of Antonio Gramsci, whose analysis of the relations among capital, social forces, and the state in post-World War I Italy provides an integrative framework that recognizes the centrality of organizations and strategy in an historical analysis of conflict and compromise. Gramscian ideas have been applied to understand labour at the workplace (Burawoy, 1979), the social status of women (Sassoon, 2000), and the emergence of a transnational élite of corporate and state managers (Cox, 1987; Gill, 1993). In this paper, we develop a neo-Gramscian conceptual framework for understanding CPS, and ground this framework in an empirical study of business engagement with the climate change issue.

\section{GRAMSGI'S POLITICS}

Perhaps Gramsci's most significant insight was that the persistence of social and economic structures in the face of the inequalities and alienation of early twentieth century capitalism is not dependent on coercive control by a small élite. Rather, hegemony rests on a broad base of consent, which relies on coalitions and compromises that provide a measure of political and material accommodation with other social groups, and on ideologies that convey a mutuality of interests. Gramsci rejected deterministic and economistic interpretations of Marx, which proposed that ideational superstructures were mere reflections of the economic base. Instead, Gramsci understood the realm of culture and ideology to be somewhat autonomous. Hegemony is rooted in the institutions of civil society, such as the church, the academy, and the media, which play a central role in ideological reproduction, providing legitimacy through the assertion of moral and intellectual 
leadership and the projection of a particular set of interests as the general interest. The institutions of civil society therefore represent a key source of stability. In a famous passage, Gramsci contrasts the relative ease with which the Russian state was overthrown in 1917 with the resilience of west European states:

When the State trembled, a sturdy structure of civil society was at once revealed. The State was only an outer ditch, behind which there stood a powerful system of fortresses and earthworks. (Gramsci, 1971, p. 238)

Civil society, in Gramsci's view, has a dual existence. As the ideological arena in which hegemony is secured, it represents part of the 'extended state', complementing the coercive potential of state agencies. However, the relative autonomy of civil society turns the ideological realm into a key site of political contestation among rival social groups and ideas. Anticipating subsequent writing by Habermas and Foucault, Gramsci argued, in his critique of economism, 'that "popular beliefs" and similar ideas are themselves material forces' (1971, p. 165) and that conflict over language is the 'cultural struggle to transform the "popular mentality" and to disseminate philosophical innovations' (cited in Fontana, 1993, p. 38). A prerequisite for social change is the development of consciousness among subordinate social groups, which requires a prolonged process of constructing educational, cultural, and political institutions in the limited autonomous space afforded within civil society.

A hegemonic social structure, or a 'historical bloc' in Gramscian terms, rests on a specific configuration of societal groups, economic structures, and concomitant ideological superstructures. A historical bloc exercises hegemony through the coercive and bureaucratic authority of the state, dominance in the economic realm, and the consensual legitimacy of civil society. Gramsci used the term historical bloc to refer to the alliances among various social groupings and also, more abstractly, to the alignment of material, organizational, and discursive formations which stabilize and reproduce relations of production and meaning: These two meanings of 'historical bloc' are closely related, for the ability to mobilize an effective alliance requires not just economic concessions but also discursive frameworks that actively constitute perceptions of mutual interests.

For Gramsci, hegemony entails (1971, pp. 181-2)

not only a unison of economic and political aims, but also intellectual and moral unity ... the development and expansion of the [dominant] group are conceived of, and presented, as being the motor force of a universal expansion ... In other words, the dominant group is coordinated concretely with the general interests of the subordinate groups, and the life of the State is conceived of as a continuous process of formation and superseding of unstable equilibria between the interests of the fundamental groups and those of the subordinate 
groups - equilibria in which the interests of the dominant group prevail, but only up to a certain point.

Hegemony is thus contingent and unstable. The economic and ideational realms evolve in dialectical tension, generating underlying fault-lines and contradictions. Historical blocs rest on insecure foundations, creating the potential for instability and change to arise endogenously as well as from external shocks. Gramsci was acutely sensitive to these dynamics: 'What is this effective reality? Is it something static and immobile, or is it not rather a relation of forces in continuous motion and shift of equilibrium?' (1971, p. 172). This understanding of the complex dynamic nature of social systems led Gramsci to emphasize the importance of agency and strategy in challenging groups with superior resources. Drawing from Machiavelli, Gramsci posited that the political party could serve as the 'Modern Prince' (1971, pp. 123-202), which should conduct a sophisticated analysis of the 'relations of forces' to reveal contradictions, weaknesses, and points of leverage, and possess the organizational capacity to intervene during critical windows of opportunity. Gramsci warned against fatalism that stems from overly deterministic accounts of history, and also against utopianism that results from excessive faith in unconstrained agency; new social structures can only arise out of the rearticulation of prior economic and ideological formations. 'The active politician is a creator, an initiator; but he neither creates from nothing nor does he move in the turbid void of his own desires and dreams. He bases himself on effective reality ... but does so in order to dominate and transcend it' (1971, p. 172).

Gramsci outlined two particular forms of strategy commonly evinced in social conflicts. The term 'passive revolution' was used to describe a process of reformist change from above, which entailed extensive concessions by relatively weak hegemonic groups, often in the guise of populist or nationalist programmes, in an effort to preserve the essential aspects of social structure. The concept of 'war of position' employed a military metaphor to suggest how groups challenging hegemonic coalitions from below might avoid a futile frontal assault against entrenched adversaries; rather, the war of position constitutes a longer term strategy, coordinated across multiple bases of power, to gain influence in the cultural institutions of civil society, develop organizational capacity, and to win new allies. As in a game of chess, power lies not just in the playing pieces, but in the configuration of forces, and each set of moves and counter-moves presents fresh possibilities to prise open the seams of a historical bloc. Successful strategy thus requires careful analysis: 'It is the problem of the relations between structure and superstructure which must be accurately posed if the forces which are active in the history of a particular period are to be correctly analyzed and the relations between them determined' (1971, p. 177).

The most sustained criticism of the Gramscian notion of hegemony is that it relies on a Marxist concept of 'false class consciousness', in which consent is 
secured through ideological control of perceptions of interest (Abercrombic et al., 1980). Alvesson and Deetz (1996) identify three problems with this 'critique of ideology' approach. First, it does not explain the conditions under which marginalized groups can evade the dominant ideology and obtain sufficient agency to engage in resistant behaviour. Second, the idea that intellectuals can stand outside the ideological system and preach to others about their real interests appears élitist and patronizing. Finally, the assumption that dominant groups can act purposefully and in unison to shape popular culture and discourse is simplistic and unrealistic. Clegg (1989), among others, has pointed out that, if one accepts Foucauldian insights concerning the pervasive and constitutive nature of discourse, then interests cannot be independently and objectively determined, implying the ontological impossibility of 'false interests'. Moreover, the dominant class is just as enmeshed in discursive structures as other social groups, and so cannot find an autonomous location from which to exercise its ideological manipulations (Willmott, 1997).

We argue that these criticisms are largely misplaced. First, we assert that it is not beyond the realm of possibility that, given the political leanings and ownership structure of the mass media, large sectors of society do, in fact, have a distorted understanding of the impact of the economic system on their wellbeing (Domhoff, 1990; McChesney, 2000). This position does not entail a reliance on some essential notion of 'objective' interests, nor that dominant classes stand 'outside of ideology'. It simply implies that people do not fully comprehend the relationships between economic structures and processes and everyday experience. Second, ideology does not carry all the burden of producing consent; hegemony is also exercised through control of economic and organizational resources, backed up by the coercive power of the state. Consent can better be understood, at least in part, as a strategic, contingent decision to comply, based on a realistic assessment of the balance of forces, a notion that is consistent with Abercrombie et al.'s (1980) description of the working class being outflanked rather than brainwashed.

Finally, agents do not need a vantage point 'outside ideology' to critique the social system; rather, agents can be positioned in the eddies and counter-currents of plural and resistant ideologies that are nurtured by the contradictions of social and economic systems and which prevail in the margins and interstices of political and cultural space (Giddens, 1984; Laclau and Mouffe, 1985; Whittington, 1992; Willmott, 1981). Hall (1986) argues that a Gramscian notion of ideology, as temporarily stabilized articulations of meaning loosely coupled to economic and political structures, steers carefully between the twin traps of structural determinism and élitist vanguardism. Gramsci linked ideology and agency in a sophisticated analysis of the role of 'organic intellectuals' in developing the consciousness, agency, and organizational preparedness of subordinate groups. In emphasizing how organic intellectuals, a 'strata of intellectuals which give a social group homo- 
geneity and an awareness of its own function, not only in the economic but also in the social and political fields' $(1971$, p. 5), are rooted in the experiences and lives of that social group, Gramsci describes a dialectical process of education, in which interests and awareness co-evolve (Freire, 1972).

Both capitalism and social theory have evolved since the 1920 s, and we need to be aware of the pitfalls of applying Gramscian theory to contemporary phenomena. Hall (1986, p. 5) notes that 'Gramsci's work does not offer a general social science which can be applied to the analysis of social phenomena across a wide comparative range of historical societies.' Germain and Kenny (1998) question the application of Gramscian thought to the international arena. Nevertheless, we concur with Hall (1986), Sassoon (2000) and Murphy (1998) that the Gramscian framework retains considerable theoretical traction for analysing the dynamics of contemporary political contests. While Gramsci's work did focus primarily on European state politics, he was also aware of the interplay of forces at international, national, and regional levels:

International relations intertwine with these internal relations of nation-states, creating new, unique and historically concrete combinations. A particular ideology, for instance, born in a highly developed country, is disseminated in less developed countries, impinging on the local interplay of combinations. This relation between international forces and national forces is further complicated by the existence within every State of several structurally diverse territorial sectors, with diverse relations of force at all levels. (1971, p. 182)

In the following section, we develop a framework for understanding corporate political strategy that draws from Gramsci's core ideas and from more contemporary theoretical perspectives, such as institutional theory. This neo-Gramscian framework offers a number of unique insights, such as the importance of coordinating economic, discursive, and organizational strategies, the potential for weaker groups to outmanoeuvre their rivals, and the significance of civil society in corporate political strategy. Overall, it suggests a strategic conception of power, that recognizes the complex relationships between structures and agents.

\section{A NEO-GRAMSGIAN FRAMEWORK FOR CORPORATE POLITIGAL STRATEGY}

We argue that Gramscian processes of negotiation, alliance formation, and compromise can be observed in multiple arenas engaging a variety of actors, from international regimes on trade and investment (Cox, 1987; Murphy, 1998) to conflicts over the welfare state (Sassoon, 2000). According to Aronowitz (1981), Gramsci's theory of the historical bloc can be applied to contemporary politics by 'building from a micropolitics of autonomous opposition movements, whether 
derived from production relations or not'. Such movements might include feminism, environmentalism, racial and ethnic groupings, and their motivations can extend beyond economic concerns to include identity and social legitimacy, as argued by theorists of 'new social movements' (McAdam et al., 1996). These contemporary interpretations replace Gramsci's ultimate revolutionary intent with a view of social contestation as an endlessly unfolding 'war of position'.

The networks of actors and concomitant material and discursive structures related to specific issue arenas closely resemble 'organizational fields' of institutional theory, particularly those renditions that attempt to integrate aspects of the 'old' institutional theory, with its attention to power and alliances (Pfeffer and Salancik, 1978), with the new emphasis on legitimacy and norms (Brint and Karabel, 1991; Fligstein, 1991; Holm, 1995). According to Hoffman (1999, p. 351), organizational 'fields become centers of debates in which competing interests negotiate over issue interpretation'. Fligstein (1996) uses the 'markets as politics' metaphor as a conceptual tool for analysing internal battles for corporate control as well as external market competition, while Granovetter (1985) sees economic institutions as embedded in broader political structures.

We propose that field-level politics can fruitfully be viewed as a contested process of assembling a historical bloc, and that the establishment of hegemony is equivalent to the process of field stabilization. Actors seek to build coalitions of firms, governmental agencies, NGOs, and intellectuals who can establish policies, norms, and institutions that structure the field in particular ways. Large firms are generally unable to dominate a field purely by virtue of brute economic power or governmental connections; rather, control over a field rests on consent from a broader group of actors. Field stabilization, or hegemony, depends on an alignment of forces capable of reproducing the field. One force is the economic system of production, taxation, and sales, with its associated distribution of costs and benefits to various groups. The second is the organizational capacity, individually and in association, of the companies, government agencies, industry associations, and elements of civil society. The third is the discursive structure of culture, ideology, and symbolism that guides behaviour and lends legitimacy to particular organizations, practices, and distributions of resources.

The neo-Gramscian approach offers a theoretically coherent way forward to those who have been attempting to integrate agency, dynamics, and power into institutional theory. $\operatorname{Holm}(1995$, p. 398) expresses the central problem of institutional theory thus: 'How can actors change institutions if their actions, intentions, and rationality are all conditioned by the very institution they wish to change?' Oliver (1992) points to performance crises, changes in the balance of power among organizational constituents with conflicting interests, and changes in the broader environment as triggers of change. Fligstein (1991, 1996) and Beckert (1999) argue that 'institutional entrepreneurs' can serve as agents of change. 
The problem with these approaches is that institutional theory primarily explains conformity and stability, and does not account well for endogenous processes that shift the balance of power or create agents willing and able to effect change. How institutional entrepreneurs escape the rules, routines, and norms of institutional fields is unclear; the trap is parallel to the 'dominant ideology' critique. Beckert (1999) turns to Schumpeter's distinction between 'managers', who simply follow institutional rules and routines, and 'entrepreneurs', who are capable of transcending institutional barriers, but does not present an adequate explanation for how they do so. Gramsci (1971, p. 172) makes a similar distinction between 'the diplomat [who] inevitably will move only within the bounds of effective reality, since his specific activity is not the creation of some new equilibrium, but the maintenance of an existing equilibrium' and the 'active politician, who wishes to create a new balance of forces'. Gramsci's active politician is, of course, the organized political party, The Modern Prince, whose agency in relationship to dominant economic and ideological structures is well developed theoretically.

Our neo-Gramscian framework links agency and dynamics by viewing institutional fields as fragmented and overlapping rather than monolithic entities with clear boundaries. We draw from Holm (1995), who suggests that institutions are nested systems in which change at one level causes change in other components of the system. Levy and Rothenberg (2002) develop this notion and argue that automobile companies are members of multiple fields exerting competing pressures, and that organizational fields can sustain multiple competing practices and discursive forms. Institutionalization is thus an ongoing but incomplete process (DiMaggio, 1988), which is never total because of the leakage of competing institutional forms from related fields and because subordinate practices and norms survive in the margins (Scott, 1994). Social movement theory has noted a similar phenomenon, in which subordinate groups maintain skeletal organizational forms and ideologies in 'abeyance structures', providing the seeds of change when conditions are ripe (Larana et al., 1994).

Combining these elements, we propose that a neo-Gramscian framework provides an integrative model in which agency and dynamics are endogenous. Organizational fields, instead of being subject to a unitary set of pressures for convergence, resemble complex dynamic systems in continuous flux and never reaching an equilibrium (Brown and Eisenhardt, 1999; Levy, 2000). Contradictions, competing ideologies, and active agents provide the motive force for system dynamics, while agents and interests are themselves constituted in field-level structures and processes. Stability of the system lies in the specific alignment of forces, and small perturbations can often be absorbed and accommodated with little impact on the overall structure. Periods of relative stability, however, are punctuated by discontinuity and change, as fissures split open and cascading reactions lead to major system-wide reconfiguration. The unfolding of social-economic systems is indeterminate due to complexity and unintended consequences, yet con- 
strained by historical trajectories. It is precisely in the space between structural determinism and unconstrained agency that the concept of strategy finds traction, providing the grounds for Gramsci's 'optimism of the will'.

It is useful to highlight some specific contributions that a neo-Gramscian perspective brings to an analysis of contested issues such as climate change. First, we might expect that actors engaged in a 'war of position' would adopt strategies that are coordinated across the three pillars of hegemony and directed toward civil society as well as the state. The drive to sustain legitimacy and a broad alliance of social actors is as important as more narrow economic activity. For example, companies under challenge on environmental issues often form issue-specific associations to lobby, mobilize resources, and coordinate strategy. They also attempt to recruit mainstream environmental organizations into the historical bloc, while marginalizing more radical groups such as Greenpeace. Where partners in civil society cannot be located, one industry tactic has been to establish organizations ostensibly representing private citizens in order to give the impression of grass roots lobbying, an activity termed 'astroturf organizing' (Stauber and Rampton, 1995). A Gramscian analysis suggests, however, that without real roots in civil society, historical blocs are likely to be weak. On the material level, companies develop regulatory and technological strategies to protect their existing markets and invest resources in environmentally preferable products and processes. On the discursive level, companies attempt to challenge the scientific and economic basis for regulation, and use public relations to portray themselves and their products as 'green', adopting the language of sustainability, stewardship, and corporate citizenship.

One implication of viewing CPS as a 'war of position' is that the traditional distinction between political and market strategies is unsustainable. Any threat to an industry's markets, whether from regulation, popular opinion, or technological innovation, is inherently a political threat; similarly, corporate response strategies to such threats, including research and development, mergers, or lobbying, can all be understood as forms of CPS. It is not just that companies can benefit from coordinating market and non-market strategies (Baron, 1997); more profoundly, this conception points to the interrelationships among 'the social and material conditions within which industry production is organized, the linkages of economic production with the social and cultural elements of life, the political and regulatory context of economic production, and the influence of production and firm strategies on the industry's economic, ecological, and social environments' (Shrivastava, 1986, p. 374). In a fundamental sense, all strategy is political.

Our account of CPS differs from power structure and élite theory perspectives in its attention to contingency, ideology, and the potential for contestation. However, the bargaining process should not be mistaken for a pluralist model in which all actors are equal. The neo-Gramscian framework brings a critical lens highlighting the influential position enjoyed by business, despite differences among 
sectors over particular policies. The influence of business extends beyond the control of material resources and the intertwining of political and economic élites. State managers are likely to protect business interests not just because of their structural dependence on business for tax revenues, employment, and investment (Block, 1987), but also because state managers have internalized the goal of promoting 'competitiveness' (Cerny, 1997; Gill, 1995). The ascendancy of a transnational historical bloc founded on a manifesto of privatization, unfettered international trade, the rollback of the welfare state, and industry self-regulation clearly sets the parameters within which individual issues are negotiated (Cox, 1994; Gill, 1993; Murphy, 1998). At the same time, individual battles at the field level are constitutive of the broader terrain of hegemony, with each concession and accommodation shifting the playing field and creating new barriers and opportunities.

Perhaps the most distinctive contribution of the neo-Gramscian approach is a strategic conception of power. Rather than see power located in resource dependencies or in the discursive framing of issues, the historical bloc suggests a specific alignment of economic, ideological, and organizational forces as the condition for field stabilization. A strategic conception of power brings attention to the capacity of agents to comprehend social structures and effect change, while simultaneously being constructed and constrained by them. Power is strategic in the sense that it is magnified through coordination of efforts in the economic, discursive, and organizational spheres; power is not simply additive. Moreover, effective strategy requires careful analysis to reveal the strengths and weaknesses of adversaries and potential allies, points of leverage, and the likely impact of each move and counter-move. Groups with fewer material resources can sometimes outmanoeuvre their rivals with clever strategy, good timing, and some luck. A more specific proposition is that the more complex a particular issue arena and the more difficult it is to foresee consequences of actions, the more opportunities exist for subordinate groups to employ strategy successfully.

\section{METHODOLOGY}

Case study methodology is most appropriate to this area of research because of the complex relations among the actors and the focus on historical processes. Case studies can provide the breadth and depth of information to allow descriptive, causative, and inductive analysis to be performed (Eisenhardt, 1989; Miles and Huberman, 1984; Yin, 1989). The case study presented here does not formally test the theoretical framework; rather, the framework evolved inductively from the case study, in a series of iterations entailing feedback from colleagues and further consideration of the data.

The research for this paper forms part of a broader project on the automobile and oil industries' responses to the climate change issue in the USA and Europe. 
These industries were selected because they face significant market and technological challenges on account of climate change, they have played a major role in the US coalition against mandatory controls, and their strategic responses differ between the USA and Europe and over time. A total of eight companies were studied, including four oil and four automobile companies, half of which were European-owned and half US-owned. Due to the degree of industry concentration and the inclusion of some of the largest companies, the study encompassed a substantial proportion of industry revenues, mitigating somewhat the problem of small sample size. Data for this study were collected from an extensive review of secondary sources and from a series of 35 semi-structured interviews conducted over an extended period from early 1998 to mid 2000. Interviews were conducted with a cross-section of firm employees, including environmental staff and managers from strategy, product development, marketing, and R\&D departments. Other interviews were performed over the telephone, using a pre-developed format. Interviews were also conducted with staff and officials from governmental agencies, environmental organizations and industry associations.

\section{GLIMATE GHANGE AS A THREAT TO HEGEMONY}

Concerns about the impact of greenhouse gases (GHGs) on the global climate system present industry with the threat of coordinated international action that could cause serious disruption to markets (Rowlands, 1995). Although scientific interest in the issue grew rapidly in the 1970s, it was the testimony of Jim Hansen of NASA before the US House Energy Committee during a June heatwave in 1988 that catapulted climate change onto corporate radar screens. Scientific reports discussed the need to reduce emissions of GHGs by 60 per cent or more to stabilize atmospheric levels. The prospect of climate change resulting from human emission of greenhouse gases challenges all three pillars of hegemonic stability. Controls on $\mathrm{CO}_{2}$ would directly threaten the revenues and profits of oil and coal companies, and raise costs for industries dependent on these fuels (Mansley, 1995). The emergence of low-emission technologies, spurred by the prospect of emission controls, poses a particular challenge to incumbent companies in fossil-fuel related industries. R\&D investments by incumbents appear highly risky because of uncertainties regarding climate science, regulatory responses, and the market potential for lowemission technologies. Moreover, there is little assurance that existing fossil fuel companies would be the winners in future markets for low emission products; unlike the ozone depletion case, where Dupont successfully led the innovation of and marketing of CFG-substitutes, technologies to address GHGs represent radical technological innovations far from the core areas of expertise of incumbent firms (Abernathy and Clark, 1985; Henderson and Clark, 1990).

In the climate issue, some companies saw not just an economic threat but a broader ideological challenge to the legitimacy of private cars. As a former VP of 
Government Relations put it, 'there are people who have cast the automobile as a villain. It is a puritanical view, that we are having too much fun, that we have too much mobility and freedom, that suburban sprawl is bad. They think we should all live in beehives.' Automobile industry managers expressed fear that the climate issue touched emotional chords which could be exploited by activist environmental groups. On the organizational level, the climate issue could strengthen the position of environmental groups, regulatory agencies, as well as nascent companies pursuing low-emission technologies. Such coalitions could push government agencies to tighten regulations such as CAFE (Corporate Average Fuel Economy) standards for automobiles or efficiency standards for power plants. Moreover, the issue was already spurring the development of international institutions, under the auspices of the United Nations, to monitor and address global environmental problems. The growth of international environmental assessments and negotiations has also expanded the organizational capacity and legitimacy of NGOs (Wapner, 1995) and communities of scientific experts (Haas, 1993).

\section{US INDUSTRY RESPONSE TO CLIMATE CHANGE}

The response by US industry was rapid and aggressive. The most immediate business response was in the organizational domain. The Global Climate Coalition (GCG) was formed in 1990, representing about 40 companies and industry associations who were major producers and users of fossil fuels. The breadth of industry represented was substantial, including coal, oil, automobiles, electric utilities, cement, aluminum, steel, chemicals, and paper. Although the GCC was constituted as a US-based organization and was focused on domestic lobbying, a number of US subsidiaries of European multinationals also joined, and the GCC quickly rose to be the most prominent voice of industry. During the $1990 \mathrm{~s}$, a number of organizational initiatives attempted to improve communication and coordination among multinational corporations (MNCs) from different countries, not always with great success. These efforts included the Business Council for Sustainable Development, which was particularly active at the UN Rio conference in 1992 (Finger, 1994) and the International Chamber of Commerce (ICC). The ICG, whose membership is primarily drawn from OEGD countries, has a very active working party on climate change which met in London in January 1996 to plan strategy for the Second Conference of the Parties (COP-2) session in Geneva in July 1996.

On the discursive level, a key strategy of the GGC in its opposition to mandatory emission controls has been to challenge the science of climate change, pointing to the lack of consensus among scientists and highlighting the uncertainties. Industry often invokes the authority of scientific discourse to deflect regulation, pointing the high standards of proof required to demonstrate causation (Edwards and Schneider, 2001). Jasanoff (1987) discusses industry's preference for 'sound 
science' as part of the political negotiation of boundaries between science and policy. The GCC uses this approach explicitly in its mission statement: 'A bedrock principle for addressing global climate change issues is that science - not emotional or political reactions - must serve as the foundation for global climate policy decisions.'

Industry challenges to the scientific basis for emission controls took a number of forms. The GCC actively promoted the views of climate sceptics in its literature, press releases, and congressional testimony, and sponsored a number of reports (Accu-Weather, 1994; Davis, 1996). Western Fuels, an association of utilities, ran an advertisement in 1993 titled 'Repeal Rio' calling climate change a 'controversial theory' with 'no support in observations', and made the claim that ${ }^{\prime} \mathrm{CO}_{2}$ fertilization of the atmosphere helps produce more food for people and wildlife'. The association also spent $\$ 250,000$ to produce a video in 1991 called The Greening of Planet Earth, which carried the same message and was apparently influential in the first Bush administration. Fossil fuel interests also funded a number of 'astroturf' groups. The Information Council for the Environment (ICE) was founded in 1991, whose purpose, as stated in internal documents, was to 'reposition global warming as theory, not fact' (Ozone Action, 1996). ICE developed a sophisticated print and radio media and set up a Science Advisory Panel which included three climate sceptics, all of whom have received funding from fossil fuel industries (Gelbspan, 1997).

Industry associations have also engaged in the public debate over the costs of reducing emissions. The GCC commissioned a series of economic studies (Montgomery, 1995; WEFA Group and H. Zinder \& Associates, 1996) which employed pessimistic assumptions concerning the responsiveness of consumers and firms to price signals. In a 1996 press release, the GCC warned that measures to curb emissions by 20 per cent 'could reduce the US gross domestic product by 4 per cent and cost Americans up to 1.1 million jobs annually'. In the run-up to the Kyoto conference in December 1997, industry's message shifted from the high cost of control measures to the unfair economic burden and limited environmental effectiveness of an agreement that would exclude developing countries from emission controls. The GCC channelled $\$ 13$ million through the Global Climate Information Project for an advertising campaign with the slogan 'It's not global and it won't work'. By emphasizing the potential implications for fuel prices and employment, the Global Climate Information Project (GCIP) secured the endorsement of a number of associations representing a spectrum of civil society, including unions, black businesses, farmers, and retired people.

These organizational and discursive strategies clearly rest on material and economic foundations. The GCC is funded by some of the world's largest MNCs, enabling it to send large delegations to international negotiations, mount expensive advertising campaigns, commission reports, and donate substantial sums to Political Action Committees to finance US Congressional election campaigns 
(Hamilton, 1998). Companies threatened by regulation of GHGs have also begun to adopt a number of defensive economic strategies. A new wave of industry consolidation has begun in the late 1990s in the oil and automobile industries, including Daimler-Chrysler, Ford-Volvo, Exxon-Mobil, Ghevron-Texaco, and BP-Amoco. These massive mergers, many of which are cross-border, strengthen the bargaining positions of key firms, provide opportunities for economies of scale, and reduce the burden of risky investments in low emission technologies. Companies have also been investing in improving the efficiency of traditional technologies, for example, through incremental improvements to diesel and gasoline engines.

The degree of coordination of economic, organizational, and discursive strategies is indicated by the fact that many MNCs established cross-functional 'climate teams' to handle the issue and industry associations such as the ICC established issue specific working groups. The coordination displayed in this case, and the attention afforded to institutions of civil society, is one of key predictions of the neo-Gramscian framework, one that is not well developed in traditional approaches to corporate political strategy.

\section{INSTABILITY AND CHANGE}

This coordinated strategy by the fossil fuel industry in the USA succeeded in securing powerful political allies in Congress. In the absence of significant public awareness on climate, the USA opposed mandatory international GHG emission controls until 1996, and entered the Kyoto negotiations in November 1997 advocating no more than a freeze on emissions at 1990 levels, while the European Union was pushing for 15 per cent reduction. By mid-1999, however, a number of writers had noted an apparent sea change in industry's stance on climate, as companies began to accept the scientific basis for emission controls and to invest significant sums in low carbon technologies (Nauss, 1999; Newswire, 1999). A simple explanation for the shift in industry position would point to the signing of the Kyoto Protocol in December 1997, committing the USA to 7 per cent reduction in emission levels, and growing scientific consensus since the IPCC's Second Assessment Report in 1995. Nevertheless, no major scientific breakthroughs had occurred, the prospects for ratification of the Protocol in the US Senate were dim, and no implementation mechanisms had been agreed. Environmental groups did not enjoy any sudden upsurge in support, neither did the fossil fuel industry lose its economic muscle.

Conventional approaches do not offer adequate explanations for industry's shift in position. Institutional theory looks to external shocks or to shifts in power relations that are themselves unexplained. Our neo-Gramscian analysis suggests that the change in the US fossil fuel industry's position is attributable to endogenous dynamics, including a series of strategic miscalculations, interactions with events 
in Europe, and shifts in the discursive, organizational, and economic spheres. A number of relatively minor developments combined to open up some of the tensions and contradictions in the historical bloc opposing mandatory emissions reductions. Industry was forced into a series of accommodations which are laying the foundation for a more stable field configuration. The emerging historical bloc is based on new organizational forms advocating for industry action on climate change, the win-win discourse of ecological modernism (Hajer, 1995), and a reconsideration of economic interests on the part of industry accompanied by modest investments in low-emission technologies. The climate regime associated with this bloc provides very limited targets for emission reductions, market-based implementation mechanisms, and minimal regulatory intrusion upon corporate autonomy.

While the industry position enjoyed strong support in the US Congress, some differences existed. Industry was seeking funds for climate-related R\&D, but Rohrabacher, Chair of the House Science Subcommittee on Energy and Environment, called any such funding 'money right down a rathole' (Gelbspan, 1997, p. 77). The State Department was concerned that US intransigence in the international negotiations could enhance Europe's leadership on the issue and affect the broader hegemonic position of the USA. The Clinton administration was almost paralysed by internal dissent over the economic impact of emission reductions, with the Department of Energy generally supportive of industry's position, the Environmental Protection Agency opposed, and Commerce split. A breach in industry ranks also became evident in the pre-Kyoto period. On 8 June 1997, the Business Roundtable sponsored full-page advertisements in the US press

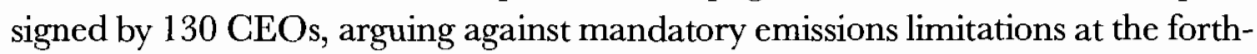
coming Kyoto conference. Eighty Business Roundtable members did not endorse the advertisements, however. Monsanto had led an unsuccessful effort to draft an alternative text, which acknowledged that sufficient scientific evidence had accumulated to warrant concern and industry's engagement in developing precautionary measures. This dissenting view was brought to President Clinton's attention at the June 1997 meeting of the President's Council of Advisers for Science and Technology (PCAST). According to Jon Holdren, Harvard scientist and chair of the PCAST panel on energy, the President's awareness of the minority industry faction had significant political ramifications: 'We actually did get the President off the dime at that meeting. He mobilized an interagency task force, and started a process which eventually converged on a set of policy recommendations for Kyoto'

The fossil fuel industry's strategies sometimes lacked effectiveness or had unanticipated consequences. One example was the attempt to undermine the credibility and legitimacy of the Inter-Governmental Panel on Climate Change (IPCC), the group of scientists conducting periodic reviews of the causes, impacts, and possibilities of mitigation of climate change, an emerging formation within global civil 
society. In May 1996, three industry associations publicly accused two lead authors of secretly altering the IPCC Second Assessment Report to reduce the expression of uncertainties (Edwards and Schneider, 2001). Despite the effectiveness of this campaign in US domestic politics, the challenge to IPCC's credibility fell short. Levy and Egan (1998) argue that the challenge had little impact on the international negotiations because the IPCC institutions had already secured a degree of autonomy and legitimacy in the international process. Moreover, the US delegation was forced to distance itself publicly from the fossil fuel lobby (Wirth, 1996).

After this affair, industry became more circumspect about challenging the science of climate change. In the run-up to Kyoto in December 1997, the GCC decided to shift its strategy from scientific uncertainties toward the high costs of mitigation and the lack of developing country commitments. This decision was based, in part, upon market research that suggested the public was not engaged with the scientific debates and did not find industry a credible source. Moreover, challenging the science was producing a backlash. Environmental groups in Europe and the USA issued a number of reports that noted industry support for some climate sceptics, and attempted to frame the issue as big business using money and power to distort the scientific debate (Corporate Europe Observatory, 1997; Friends of the Earth International, 1997; Gelbspan, 1997; Hamilton, 1998). A Ford executive acknowledged that 'appearing negative hurts. We lost the first round of battles. We are now trying to be more positive with the science, while still pointing to the high cost of precipitate action. Our actions will be less strident in the future.'

The failure of the fossil-fuel industry's challenge can be understood, in terms of our framework, as a sequence of strategic miscalculations combined with countermoves by environmental groups in the key realm of civil society. The GCC's efforts clearly demonstrated a concern for the mantle of scientific legitimacy, yet the IPCC scientists were much more entrenched in civil society at the national level as well as within the international climate institutions than the few climate sceptics. Moreover, industry's efforts at 'astroturf organizing' only highlight the shallow and artificial nature of support within civil society for industry's position. At best, the GCC's efforts created some cover for politicians allied to fossil fuel industry interests and created some confusion among the public. It should be noted, however, that environmental NGOs, while successful in discrediting some industry initiatives, did little better in building a strong grassroots campaign, preferring instead to pursue an élite-level strategy that targeted the corridors of power in Washington DC (Dowie, 1995).

The importance of projecting moral and intellectual leadership in sustaining hegemony is reflected in the American Petroleum Institute's (API) opposition to the GCC's decision in 1997 to downplay the role of climate science. The API prepared a new 'Global Climate Science Communications Plan' to enrol a group of climate sceptics who were not previously identified with the fossil fuel lobby. In 
internal documents leaked to the National Environmental Trust and the New York Times (National Environmental Trust, 1998), the API expressed concern that the US media conveyed an impression of emerging scientific consensus 'while industry and its partners ceded the science and fought on the economic issues'. The document argued that this stance was miscalculated because a successful campaign to challenge the science 'puts the United States in a stronger moral position and frees its negotiators from the need to make concessions as a defense against perceived selfish economic concerns'. An auto industry public relations executive made a similar point: 'Once you concede the science, all that is left is to argue the extent of liability and the timetable for emission reductions. It's a lost cause.' It was, indeed, a lost cause, and by late 1997 the business press in the USA and Europe was conveying the impression of scientific consensus (Raeburn, 1997; Stipp, 1997; The Economist, 1997).

The overlapping and nesting of organizational fields implies that developments in one country or industry can disrupt the balance of forces elsewhere. For example, the landmark speech by British Petroleum's Group Chief Executive, John Browne on 19 May 1997 represented a major fissure in the oil industry's position, which bore implications for other industries in Europe and in the USA. While acknowledging that considerable scientific uncertainties still existed, Browne stated 'The time to consider the policy dimensions of climate change is not when the link between greenhouse gases and climate change is conclusively proven, but when the possibility cannot be discounted and is taken seriously by the society of which we are part.' This invocation of the precautionary principle, which held more discursive currency in Europe, directly challenged the 'sound science' approach advocated by US industry. Managers from other oil and automobile companies commented on how Browne's speech triggered an internal reevaluation of strategy and increased external pressure to respond.

The European automobile industry found itself in a particularly weak position, in which politicians looked to the industry for substantial, early emission reductions. Germany, with a well organized green political party, had unilaterally committed to significant GHG reductions during the negotiations in Berlin in 1994 and had pushed the German auto industry association into a 'voluntary' agreement to reduce $\mathrm{CO}_{2}$ emissions from new cars by 25 per cent. Concerned about the competitiveness of its national automobile companies, Germany then pushed the European Union (EU) to adopt similar measures. The EU was sensitive to accusations from the Americans that it talked a tough position but lacked any will to implement. The European Commission introduced a proposal to reduce average $\mathrm{CO}_{2}$ emissions from new cars from $186 \mathrm{~g} / \mathrm{km}$ to $120 \mathrm{~g} / \mathrm{km}$ by 2005 (equivalent to about $45 \mathrm{mpg}$ ). European automobile companies avoided direct challenges to the scientific need for emission controls, with various managers calling any such effort 'futile' and 'inappropriate'. After three years of negotiations, during which major rifts between the European oil and automobile industries became apparent, 
the European Automobile Industry Association (ACEA) accepted a voluntary agreement in 1998 to reduce emissions to $140 \mathrm{~g} / \mathrm{km}$ by 2008 (Bradsher, 1998).

From a European perspective, with regulation of emissions appearing inevitable, oil and auto companies began to make substantial investments in low-emission technologies. BP and Shell made large commitments to renewable energy (Boyle, 1998), and Daimler-Chrysler invested $\$ 400$ million in a fuel cell joint venture. USbased MNCs, engaged in international competition and fearing a loss of technological leadership, felt compelled to respond. The commercial launch by Toyota and Honda of gas-electric hybrid vehicles compounded this pressure. Ford joined Daimler, investing another $\$ 400$ million in the fuel cell venture with the Canadian company Ballard, while GM has formed an alliance with Toyota to invest in a range of technologies. One Ford VP remarked, 'Of course we are concerned about what competitors are doing. Any insights into consumer demands are a scarce and valuable commodity. Maybe we have missed something.' The scale and risk of these investments is one factor driving the current wave of mergers and alliances, reshaping the economic structure of these industries.

In the oil industry, market outlooks have converged significantly in a manner which facilitates the coordination of the interests of companies with a regime to control greenhouse gas emissions. All four companies interviewed expected oil production to peak around 2020 to 2030, with a slow subsequent decline. None of the companies expected renewables to pose major threats to oil and gas before mid-century due to cost and infrastructure limitations. Although the companies had all initially perceived climate change to be a serious business threat, Shell and Exxon concurred that the outlook was strong in the medium term; demand for gas for power generation was booming even without carbon controls. Oil was used primarily for transportation, and any improvements in fuel efficient would be more than offset by growth in vehicle sales and miles travelled, particularly in developing countries. Air transportation was growing rapidly. Fuel cells for vehicles still faced many cost and technical barriers, and in the medium term would utilize hydrogen derived from oil-based hydrocarbons.

Accompanying this shift in perceptions of economic interests, the 'win-win' discourse of 'ecological modernization' (Hajer, 1995), which asserts the mutuality of business and environmental interests, has rapidly gained ground in the climate debate (Casten, 1998; Romm, 1999). Ecological modernization puts its faith in the technological, organizational, and financial resources of the private sector, voluntary partnerships between government agencies and business, flexible marketbased measures, and the application of environmental management techniques (Hart, 1997; Schmidheiny, 1992). The win-win paradigm is a key discursive foundation for the emerging climate compromise and a more stable historical bloc. A number of industry associations active on the climate issue, such as the Business Council for Sustainable Energy (BCSE) and the World Business Council for Sustainable Development, have adopted this language. Influential environmental 
NGOs in the USA, especially the World Resources Institute and the Environmental Defense Fund (Dudek, 1996), advocate this perspective and have initiated partnerships with business to pursue profitable opportunities for emission reductions. Business school professors have become the movement's 'organic intellectuals' (Reinhardt, 2000). Governmental agencies find 'win-win' rhetoric attractive for reducing conflict in policy making. In the USA, the joint EPA/Department of Energy Climate Wise programme describes itself as 'a unique partnership that can help you turn energy efficiency and environmental performance into a corporate asset' (US DoE, 1996).

The growth of new organizations committed to a climate compromise has undermined the GCC's claim to be the voice of industry on climate. Eileen Claussen, a former US Assistant Secretary of State for Environmental Affairs and negotiator at the climate change negotiations, formed the Pew Center on Global Climate Change in April 1998. The Pew Center provides not only a channel of policy influence for member companies, but also a vehicle for legitimizing the new position. Thirteen companies joined immediately, including BP, Toyota, Boeing, Enron, United Technologies, American Electric Power, Whirlpool, and 3M. These companies endorsed a series of newspaper advertisements stating that they 'accept the views of most scientists that enough is known about the science and environmental impacts of climate change for us to take actions to address its consequences' (Cushman, 1998). Business sectors associated with low carbon technologies have become stronger economically, and have increasingly exerted their collective voice. The BCSE, for example, which has affiliates in the USA and Europe, represents insulation manufacturers and the fragmented renewable energy sector, comprising many small companies active in solar and wind energy. Increasingly, however, it has attracted larger companies engaged in natural gas and electronic controls, including Honeywell, Enron, and Maytag.

Environmental activists and NGOs have played an active role trying to broaden the alliance of industries supportive of emission controls. Of particular note have been the efforts of Jeremy Leggett, formerly of Greenpeace International, to gain the support of banking and insurance companies, whose assets could be at increased risk from climate-related property damage (Tucker, 1997). Leggett has been instrumental in educating insurance companies about the potential risks and has successfully worked with some of them to take a more active role in the international climate negotiations (Leggett, 1999). It would be overstating the case, however, to suggest that environmental NGOs have successfully played the role of Gramsci's Modern Prince, tightly coordinating their strategic moves to outmanoeuvre their industry adversaries. Rather, the original historical bloc, facing loosely coordinated opposition and a series of pressures on a number of fronts, became unstable and in danger of collapsing like a house of cards. The GCC was weakened by a series of defections: BP left in late 1997, Shell in 1998, and Ford 
in 1999. In early 2000 , the GCC was reorganized to represent industry associations rather than individual member companies.

The emerging climate regime represents a reconstituted historical bloc rather than a thorough revolution. Gramsci's concept of 'passive revolution' is particularly apt to describe the way in which major firms and states have made significant accommodations without ceding their dominant market and political positions. The nascent historical bloc is based on a reconfiguration of the alliances among firms, states, NGOs, and assorted professionals, primarily scientists and economists, and a realignment of economic, organizational, and ideological forces. The Kyoto Protocol and the accompanying rhetoric of sustainable development provide economic and ideological mechanisms to coordinate the interests of major actors, particularly by reducing compliance costs and creating financial incentives. Indeed, the USA provided an explicit assurance that industry interests would be accommodated at the negotiations in Geneva in July 1996, when the US first agreed to a binding international agreement. Chief negotiator Tim Wirth (1996) promised that the USA would pursue 'market-based solutions that are flexible and cost-effective', and that 'meeting this challenge requires that the genius of the private sector be brought to bear on the challenge of developing the technologies that are necessary to ensure our long term environmental and economic prosperity'.

The main elements of the Protocol include mandatory but modest emission targets, which are substantially weakened by broad and flexible mechanisms for implementation and by weak enforcement. The withdrawal of the USA in early 2001, while not torpedoing the agreement, gave more leverage to Japan, Russia, and Australia to bargain for this flexibility, so that the final agreement more closely resembles a treaty which the USA might, in fact, join in the future. The inclusion of carbon sinks from forest and land use changes introduces considerable uncertainty and room for creative accounting due to the difficulty in establishing baselines and measuring changes. The ability to buy carbon credits in international emission trading schemes, which the EU had tried to limit, enables ex-Soviet Bloc countries to sell large amounts of 'hot air' credits, which are available due to their industrial collapse since 1990. The various systems for trading carbon credits reduce the adjustment burden on industry and create profit opportunities for firms selling low-emission technologies (Grubb et al., 1999).

The international treaty puts a formal face on an informal greenhouse gas governance regime whose contours reflect the conflicts and compromises that constitute the emerging historical bloc. Several countries, including the UK, have been designing national energy and carbon taxes, while the EU has been preparing a regional carbon-trading system. Many companies, viewing an emission cap as inevitable at some point, have begun to inventory their emissions and invest in lowemission technologies; Alcoa, for example, has been testing new smelting processes 
that could greatly cut releases of both carbon dioxide and perfluorocarbons, and announced plans to reduce its greenhouse emissions by 2010 to levels 25 per cent below those in 1990. BP has committed to internal emission cuts and to an internal trading system. More ambitiously, scveral private initiatives have been established to create a carbon trading system among participating companies. In 2000, the NGO Environmental Defense formed The Partnership for Climate Action, which international companies are invited to join in order to develop an emission trading scheme. The World Bank Prototype Carbon Fund (PGF) was established in 2000 as a 'public-private partnership' between a few national governments, including the Netherlands, Sweden, Japan, and Canada, and 26 companies, including Hydro Quebec, Daimler-Chrysler, Shell-Canada, and BP-Amoco. The Fund's purpose is to raise $\$ 140$ million for investments in renewables and efficiency in developing countries, projects that will earn carbon credits for the investing companies under provisions of the Kyoto Protocol.

\section{GONCLUSIONS}

Corporate political strategy can be understood as part of the process of conflict and accommodation between business and social groups within particular issue arenas. Gramsci's theoretical approach to understanding the process of social contestation can be extended to encompass multiple social actors competing for influence over the rules, institutions, norms, and policies that structure markets and economic relations. The neo-Gramscian framework provides a perspective that is theoretically grounded, reflects material, discursive, and organizational dimensions of power, and points to the importance of strategy in effecting change within complex social systems. By viewing corporate political strategy as the struggle to build or defend a hegemonic position in a specific field of actors, the framework provides an integrative approach that overcomes the dichotomy between market and non-market strategies. The neo-Gramscian perspective draws insights from other theoretical approaches, but offers a particular contribution to institutional theory by presenting a framework which addresses some of the tensions of the agency-structure relationship, provides a concept of ideology that avoids problems of elitism and essentialism, and incorporates dynamics endogenously. Moreover, the neo-Gramscian framework presents a strategic notion of power which suggests how actors can gain at least partial comprehension of and influence over complex social and political systems.

The framework illuminates a number of aspects of the case study on climate change which are not well explained by other approaches. Efforts by the fossil fuel industry to preserve its hegemonic position, in terms of market dominance, autonomy, and policy influence, can be understood in terms of a 'war of position' in which actors coordinate sources of power and build alliances. In particular, the neo-Gramscian approach points to the crucial role of civil society, the significance 
of political struggles over climate science and economics, and the ultimate weakness of 'astroturf' strategies on the part of industry. The framework also provides insight into the dynamics of the climate change issue-level organizational field. Even in the absence of external shocks, a number of developments in the economic, discursive, and organizational realms moved the field out of alignment and opened up tensions in the historical bloc. Fossil fuel companies, after a series of strategic miscalculations, were forced to move toward a strategy of accommodation, or 'passive revolution'. Actors supportive of emission controls were able to manoeuvre deftly through the complex terrain of the international negotiations and construct a coalition whose interests were sufficiently articulated on economic and discursive levels and which could present a sense of moral and intellectual leadership. The specific contours of the emerging climate regime, which provides for modest emission cuts but secures the broader hegemonic position of affected industries, can be understood in terms of the historical process of reconfiguring an unstable bloc.

It is somewhat ironic that the new Bush administration in the USA pulled out of the Kyoto Protocol in 2001, just as much of American industry appeared willing to acommodate mandatory international emission controls. The Bush administration, of course, has particularly strong ties to the oil industry (Democratic Policy Committee, 2001) and, at first glance, the new US position provides evidence of direct, instrumental corporate power rather than the Gramscian concept of negotiated hegemony. Indeed, even before the accession of Bush to the White House, an anonymous oil industry source interpreted the disbanding of the GCC in its traditional form not as a failure but rather as a case of 'mission accomplished; now we can avoid the political cost of membership'. However, the Kyoto process appears to be moving forward even without the participation of the USA, and in July 2001, 178 countries agreed to implementation measures. Even in the USA, some energy companies have been lobbying for the adoption of emission controls, as they already are positioning themselves to compete in a carbon-constrained world and generate valuable carbon credits (Revkin and Banerjee, 2001). The inexorable momentum of the entire system, even in the face of US opposition, points to the power of the new alignment of forces. Gramsci himself noted (1971, p. 174) that in the face of particular economic and ideological configurations, 'International relations deal with a balance of forces in which any single State component has only a very limited weight.'

Of course, the current situation is just one phase in a protracted war of position. New sources of tension are not hard to find; developments in low-emission technologies and markets, compromises needed to bring the USA and less developed countries into the fold, evolving scientific understanding of the climatic system, could all provide fuel for field instability and dynamics. It remains to be seen whether the new terrain of contestation protects the position of traditional energy-related businesses or provides new strategic opportunities for challengers. 


\section{NOTE}

*The authors thank William Domhoff, Tom Gladwin, John Jermier, Vivien Schmidt, Hugh Willmott, and three anonymous reviewers for comments on earlier drafts of this paper. The authors gratefully acknowledge financial support for this project from the Global Environmental Assessment Project, Kennedy School of Government, Harvard University; the Consortium on Environmental Challenges, Massachusetts Institute of Technology; and from the University of Massachusetts, Boston.

\section{REFERENCES}

Abercrombie, N., Hill, S. and Turner, B. S. (1980). The Dominant Ideology Thesis. London: Allen and Unwin.

Abernathy, W. J. and Clark, K. B. (1985). 'Innovation: mapping the winds of creative destruction'. Research Policy, 14, 3-22.

Accu-Weather, I. (1994). Changing Weather: Facts and Fallacies about Climate Change and Weather Extremes. State College, PA: Accu-Weather, Inc.

Akard, P. J. (1992). 'Corporate mobilization and political power: the transformation of U.S. economic policy in the 1970s'. American Sociological Review, 57, 597-615.

Alvesson, M. and Deetz, S. (1996). 'Critical theory and postmodernism approaches to organizational studies'. In Clegg, S. R., Hardy, C. and Nord, W. R. (Eds), Handbook of Organization Studies. Thousand Oaks, CA: Sage, 191-217.

Aronowitz, S. (1981). The Crisis in Historical Materialism: Class, Politics, and Culture in Marxist Theory. Minneapolis: University of Minnesota Press.

Baron, D. P. (1997). 'Integrated strategy, trade policy, and global competition'. California Management Review, 39, 145-69.

Beckert, J. (1999). 'Agency, entrepreneurs, and institutional change'. Organization Studies, 20, 777-99.

Block, F. (1987). Revising State Theory. Philadelphia: Temple University Press.

Boddewyn, J. (1988). 'Political aspects of MNE theory'. Fournal of International Business Studies, 19, Fall, $341-63$.

Boyle, S. (1998). 'Early birds and ostriches'. Energy Economist, May, London, 12-17.

Bradsher, K. (1998). 'European Auto Division calling for improved fuel economy'. New York Times, 26 April, 24.

Brint, S. and Karabel, J. (1991). 'Institutional origins and transformations: the case of American community colleges'. In Powell, W. W. and DiMaggio, P. J. (Eds), The New Institutionalism in Organizational Analysis. Ghicago: University of Chicago Press, 337-60.

Brown, S. L. and Eisenhardt, K. M. (1999). Competing on the Edge: Strategy as Structured Chaos. Boston: Harvard Business School Press.

Burawoy, M. (1979). Manufacturing Consent: Changes in Labor Process under Capitalism. Chicago: University of Chicago Press.

Buttel, F. H. (1998). 'Some observations on states, world orders, and the politics of sustainability'. Organization and Environment, 11, 261-86.

Casten, T. R. (1998). Turning off the Heat. Amherst, NY: Prometheus Books.

Cerny, P. G. (1997). 'The dynamics of political globalization'. Government and Opposition, 32, 251-74.

Clegg, S. (1989). Frameworks of Power. London: Sage.

Corporate Europe Observatory (1997). The Weather Gods: How Industry Blocks Progress at Kyoto Climate Summit. Amsterdam: Corporate Europe Observatory.

Cox, R. W. (1987). Production Power, and World Order. New York: Columbia University Press.

Cox, R. W. (1994). 'The crisis in world order and the challenge to international organization'. Cooperation and Conflict, 29, 99-113.

Cushman, J. H. J. (1998). 'New policy center seeks to steer the debate on climate change'. The Nere Tork Times, 8 May.

Davis, R. E. (1996). Global Warming and Extreme Weather: Fact vs. Fiction. Washington DG: Global Climate Coalition.

Democratic Policy Committee (2001). GOP Great Oil Payback. Washington DG: Democratic Party. 
DiMaggio, P. J. (1998). 'Interest and agency in institutional theory'. In Zucker, L. (Ed.), Institutional Patterns of Organization. Cambridge, MA: Ballinger Publishing Company, 3-21.

Domhoff, G. W. (1990). The Power Elite and the State: How Policy is Made in America. New York: Aldine de Gruyter.

Dowie, M. (1995). Lasing Ground: American Environmentalism at the Close of the Twentieth Century. Cambridge, MA: MIT Press.

Dudek, D. J. (1996). Emission Budgets: Creating Rewards, Lowering Costs and Ensuring Results. New York: Environmental Defense Fund.

Edwards, P. N. and Schneider, S. H. (2001). 'Self-governance and peer review in science-for-policy: the case of the IPCC Second Assessment Report'. In Miller, C. A. and Edwards, P. N. (Eds), Changing the Atmosphere: Expert Knoweledge and Environmental Governance. Cambridge, MA: MIT Press, 219-46.

Eichenwald, K., Kolata, G. and Petersen, M. (2001). 'Biotechnology food: from the lab to a debacle'. New York Times, 25 January. http://www.nytimes.com/2001/01/25/business/25FOOD.html.

Eisenhardt, K. M. (1989). 'Building theories from case study research'. Academy of Management Revieze, 14, 532-50.

Ferguson, T. (1995), Golden Rule. Chicago: University of Chicago Press.

Finger, M. (1994). 'Environmental NGOs in the UNCED process'. In Princen, T. and Finger, M. (Eds), Environmental NGOs in World Politics. New York: Routledge, 186-213.

Fligstein, N. (1991). 'The structural transformation of American industry: an institutional account of the causes of diversification in the largest firms: 1919-1979'. In Powell, W. and DiMaggio, P. (Eds), The New Institutionalism in Organizational Analysis. Chicago: University of Chicago Press, 311-36.

Fligstein, N. (1996). 'Markets as politics: a political cultural approach to market institutions'. American Sociological Review, 61, 656-73.

Fontana, B. (1993). Hegemony and Power: On the Relation between Gramsci and Machiavelli. Minneapolis: University of Minnesota Press.

Freire, P. (1972). The Pedagogy of the Oppressed. Harmondsworth: Penguin.

Friends of the Earth International (1997). Lobbying for Lethargy: The Fossil Fuel Lobby and Climate Change Negotiations. London: Friends of the Earth International.

Gelbspan, R. (1997). The Heat Is On. Reading, MA: Addison Wesley.

Germain, R. D. and Kenny, M. (1998). 'Engaging Gramsci: international theory and the new Gramscians'. Review of International Studies, 24, 3-21.

Giddens, A. (1984). The Constitution of Society: Outline of the Theory of Structuration. Berkeley, CA: University of California Press.

Gill, S. (Ed.) (1993). Gramsci, Historical Materialism and International Relations. Cambridge: Cambridge University Press.

Gill, S. (1995). 'Globalisation, market civilisation, and disciplinary neoliberalism'. Millenium: Journal of International Studies, 24, 399-423.

Gramsci, A. (1971). Selections from the Prison Notebooks (Hoare, Quintin; Nowell-Smith, Geoffrey, Trans.). New York: International Publishers.

Granovetter, M. (1985). 'Economic action and social structure: the problem of embeddedness'. American Journal of Sociology, 91, 481-510.

Grubb, M., Vrolijk, C. and Brack, D. (1999). The Kyoto Protocol: A Guide and Assessment. London: RIIA/Earthscan.

Haas, P. M. (1993). 'Epistemic communities and the dynamics of international environmental cooperation'. In Rittberger, V. (Ed.), Regime Theory and International Relations. Oxford: Clarendon Press.

Hajer, M. A. (1995). The Politics of Environmental Discourse: Ecological Modernization and the Policy Process. Oxford: Clarendon Press.

Hall, S. (1986). 'Gramsci's relevance for the study of race and ethnicity'. Fournal of Communication Inquiry, 10, 5-27.

Hamilton, K. (1998). The Oil Industry and Climate Change. Amsterdam: Greenpeace International.

Hart, S. L. (1997). 'Beyond greening: strategies for a sustainable world'. Harvard Business Review, 75, 1, January-February, 66-76.

Henderson, R. and Clark, K. B. (1990). 'Architectural innovation: the reconfiguration of existing product technologies and the failure of established firms'. Administrative Science Quarterly, 35, 9-30. 
Hillman, A.J. and Hitt, M. A. (1999). 'Corporate political strategy formulation: a model of approach, participation, and strategy decisions'. Academy of Management Review, 24, 825-42.

Hillman, A. and Keim, G. (1995). 'International variation in the business-government interface: institutional and organizational considerations'. Academy of Management Review, 20, 193-214.

Hoffman, A. J. (1999). 'Institutional evolution and change: environmentalism and the U.S. chemical industry'. Academy of Management fournal, 42, 351-71.

Holm, P. (1995). 'The dynamics of institutionalization: transformation processes in Norwegian fisheries'. Administrative Science Quarterly, 40, 398-422.

Jasanoff, S. S. (1987). 'Contested boundaries in policy-relevant science'. Social Studies of Science, 17, 195-230.

Korten, D. C. (1995). When Corporations Rule the World. West Hartford, CT: Kumarian Press.

Laclau, E. and Mouffe, C. (1985). Hegemony and Socialist Strategy; Toward a Radical Democratic Politics. New York: Verso.

Larana, E., Johnston, H. and Gusfield, J. R. (Eds) (1994). New Social Movements: from Ideology to Identity. Philadelphia: Temple University Press.

Leggett, J. (2000). The Carbon War: Dispatches from the End of the Oil Century. London: Penguin Books.

Levy, D. L. (1997). 'Environmental management as political sustainability'. Orgamization and Enizionment, 10, 12647.

Levy, D. L. (2000). Applications and limitations of complexity theory in organization theory and strategy'. In Rabin, J., Miller, G. J. and Hildreth, W. B. (Eds), Handbook of Strategic Management, 2nd ed. New York: Marcel Dekker.

Levy, D. L. and Egan, D. (1998). 'Capital contests: national and transnational channels of corporate influence on the climate change negotiations'. Politics and Society, 26, 337-61.

Levy, D. L. and Rothenberg, S. (2002). 'Heterogeneity and change in environmental strategy: technological and political responses to climate change in the automobile industry'. In Hoffman, A. and Ventresca, M. (Eds), Organizations, Policy and the Natural Environment: Institutional and Strategic Perspectives. Stanford: Stanford University Press.

Mahon, J. (1983). 'Corporate political strategies: an empirical study of chemical firm responses to superfund legislation'. In Preston, L. (Ed.), Research in Corporate Social Performance and Policy, Vol. $5,143-82$.

Mansley, M. (1995). Long Term Financial Risks to the Carbon Fuel Industry from Climate Change. London: The Delphi Group.

McAdam, D., McCarthy, J. and Zald, M. (1996). Comparative Perspectives on Social Movements. New York: Cambridge University Press.

McChesney, R. W. (2000). Rich Media, Poor Democracy: Communication Politics in Dubious Times. Champaign, IL: University of Illinois Press.

Miles, M. B. and Huberman, A. M. (1984). Qualitative Data Analysis: A Sourcebook of New Methods. Newbury Park, CA: Sage.

Mills, C. W. (1967). The Power Elite. New York: Oxford University Press.

Minnick, B. M. (1993). 'Political contestability'. In Mitnick, B. M. (Ed.), Corporate Political Agency. Newbury Park, CA: Sage, 11--66.

Mizruchi, M. S. (1992). The Structure of Corporate Political Action: Interfirm Relations and their Consequences. Cambridge MA: Harvard University Press.

Montgomery, D. W. C. R. A. (1995). Toward an Economically Rational Response to the Berlin Mandate. Washington DC: Charles River Associates.

Murphy, C. N. (1998). 'Understanding IR: understanding Gramsci'. Rernew of International Studies, 24, 417-25.

National Environmental Trust (1998). Climate Bulletin: Big Oil's Secret Plan to Block the Global Warming Treaty (Press release www.envirotrust.com/re198apr27.html). Washington DG: National Environmental Trust.

Nauss, D. W. (1999). 'Auto makers are finding it's not easy being "green"'. Los Angeles Timmes, 28 January.

Newell, P. and Paterson, M. (1998). 'A climate for business: global warming, the state and capital'. Review of International Political Economy, 5, 679-703.

Newswire, U. (1999). 'ABB, Intenergy, Shell International join growing corporate effort to address climate change'. US Newswire, 11 February.

Oliver, C. (1992). 'The antecedents of deinstitutionalization'. Organization Studies, 13, 563-88. 
Ozone Action (1996). Distorting the Debate: A Case Study of Corporate Greenwashing. Washington, DC: Ozone Action.

Pfeffer, J. and Salancik, G. R. (1978). The External Control of Organizations: A Resource Dependence Perspective. New York: Harper and Row.

Raeburn, P. (1997). 'Global warming: is there still room for doubt?' Businessweek, 3 November, 158.

Rcinhardt, F. L. (2000). Dowen to Earth: Applying Business Principles to Environmental Management. Boston: Harvard Business School Press.

Revkin, A. C. and Banerjee, N. (2001). 'Energy executives urge some gas-emission limits on Bush'. New Tork Times.

Robinson, W. (1996). Promoting Polyarchy: Globalization, US Intervention, and Hegemony. New York: Cambridge University Press.

Romm, J. R. (1999). Cool Companies: How the Best Businesses Boost Profits and Productivity by Cutting Greenhouse Gas Emissions. Washington, DC: Island Press.

Rowlands, I. H. (1995). The Politics of Global Almospheric Change. Manchester: Manchester University Press.

Sassoon, A. S. (2000). Gramsci and Contemporary Politics: Beyond Pessimism of the Inteilect. London: Routledge.

Schmidheiny, S. (1992). Changing Course. Cambridge, MA: MIT Press.

Scott, W. R. (1994). 'Institutions and organizations: toward a theoretical synthesis'. In Scott, W. R. and Meyer, J. W. (Eds), Institutional Environments and Organizations. Thousand Oaks, CA: Sage.

Shaffer, B. (1995). 'Firm-level responses to government regulation: theoretical and research approaches'. Fournal of Management, 21, 495-514.

Shrivastava, P. (1986). 'Is strategic management ideological?'. Journal of Management, 12, 363-77.

Smythe, E. (2000). 'State authority and investment security: non-state actors and the negotiation of the Multilateral Agreement on Investment at the OECD'. In Higgott, R. A., Underhill, G. R. D. and Bieler, A. (Eds), Non-state Actors and Authority in the Global System. London: Routledge, 74-90.

Stauber, J. C. and Rampton, S. (1995). Toxic Sludge is Good for You. Monroe, ME: Common Courage Press.

Steger, U. (1993). 'The greening of the board room: how German companies are dealing with environmental issues'. In Fischer, K. and Schot, J. (Eds), Environmental Strategies for Industry. Washington DG: Island Press.

Stipp, D. (1997). 'Science says the heat is on'. Fortune Magazine, 8 December, 126.

The Economist (1997). 'Sharing the greenhouse'. The Economist, 11 October.

Tucker, M. (1997). 'Climate change and the insurance industry: the cost of increased risk and the impetus for action'. Ecological Economics, 22, 85-96.

US DoE (1996). Climate Wise DOE/EE-0071, EPA 230-K-95-003. Washington, DC: US DoE.

Useem, M. (1984). The Inner Circle. New York: Oxford University Press.

Vogel, D. J. (1996). The study of business and politics'. California Management Reviere, 38, 146-65.

Wapner, P. (1995). 'Politics beyond the state: environmental activism and world civic politics'. World Politics, 47, 311-40.

WEFA Group and H. Zinder \& Associates (1996). A Review of the Economic Impacts of AOSIS-type Proposals to Limit Carbon Dioxide Emissions (prepared for Global Climate Coalition). Eddystone, PA: WEFA Group.

Weidenbaum, M. L. (1981). Business, Government, and the Public. Englewood Gliffs, NJ: Prentice Hall.

Whittington, R. (1992). 'Putting Giddens into action: social systems and managerial agency'. Fournal of Management Studies, 29, 493-512.

Willmott, H. (1981). 'The structuring of organizational structure'. Administrative Science Quarterly, 26, $470-4$.

Willmott, H. (1997). 'Rethinking management and managerial work: capitalism, control, and subjectivity'. Human Relations, 50, 11, 1329-60.

Wirth, T. E. (1996). Statement by Timothy E. Wirth, Under Secretary for Global Affairs, on behalf of the United States of America, at Convention on Climate Change, second Conference of the Parties, 17 July. Geneva, Switzerland: United States Mission, Office of Public Affairs.

Yin, R. K. (1989). Case Study Research: Design and Methods. Newbury Park, CA: Sage.

Yoffic, D. B. and Bergenstcin, S. (1985). 'Creating political advantage: the rise of the corporate political entrepreneur'. California Management Retrew, 28, 124-39. 